\title{
Learning the English Passive Voice: A Comparative Study on Input Flooding and Input Enhancement Techniques
}

\author{
M. Rashtchi ${ }^{1} \&$ F. Etebari ${ }^{1}$ \\ ${ }^{1}$ TEFL Department, Faculty of Foreign Languages, Islamic Azad University, North Tehran Branch, Iran \\ Correspondence: Mojgan Rashtchi, TEFL Department, Islamic Azad University, Tehran, 1651153311, Iran. Tel: \\ 98-2177-317-702. E-mail: mojgan.rashtchi@gmail.com, m_rashtchi@iau-tnb.ac.ir
}

Received: May 4, 2018; Accepted: May 12, 2018; Published: May 18, 2018

\begin{abstract}
The purpose of this study was to compare the effect of input flooding and input enhancement on grammar knowledge of passive voice among Iranian EFL learners. Preliminary English Test (PET) was administered to 75 learners who were in six intact classes in a language institute in Tehran. Sixty female low-intermediate learners whose scores fell within the range of \pm 1 standard deviation were selected. These classes were then randomly assigned to receive two different treatments. Three classes in the experimental group one (Input Enhancement Group) were exposed to passive structures through input enhancement guidelines, and the three classes in the experimental group two (Input Flooding Group) received the same materials drawing on the guidelines in line with input flooding procedures. It should be noted that the 15 discarded participants were present in the classes, but their scores were not considered in the data analysis. The reason for selecting six classes was the limited number of students in each class. However, the classes were taught by the same teacher to control teacher variable. The results of the pretest showed that the groups were homogeneous regarding their knowledge about the English passive voice. After the treatment, the participants sat for the posttest, which was identical to the pretest to measure their gain of the passive structures. The results indicated that both input flooding and input enhancement significantly affected the grammar knowledge of the passive voice. However, there was no statistically significant difference between the effects of input flooding and input enhancement in improving the knowledge of passive voice of the participants.
\end{abstract}

Keywords: input enhancement, input flooding, English grammar, passive voice

\section{Introduction}

\subsection{Introducing the Problem}

There is a unanimous agreement on the role of sufficient amount of input for learning a language in the domain of SLA. However, as Swain (1988) put forth, there are particular forms of language that are learned with difficulty or are not learned at all which could partially be due to the learners' first language system. Thus, many scholars suggest different types of manipulation of input that could facilitate learning features of a language. However, the suggestion has given rise to the explicit/implicit dichotomy. The review of the literature shows that it is not possible for learners to develop accuracy without some explicit teaching of grammar. Input enhancement and input flooding as two types of Focus on Form (FonF) instruction (Doughty \& Williams, 1988) that can facilitate learning the forms of language intend to draw learners' attention to the rules of the language.

Input enhancement first introduced by Sharwood-Smith $(1991,1993)$ refers to directing the learners' attention to particular structures of the target language. Input enhancement, according to Sharwood-Smith, could be either in the form of manipulation of the input such as typographical enhancement or explicit instruction and corrective feedback. The present study was concerned with drawing learners' attention to the target structures through textual enhancement. Through input flooding, on the other hand, learners are exposed to numerous examples of a structure in a text to attract learners' attention (Wagner-Gough \& Hatch, 1975). As Gass and Selinker (2001) noted, the idea behind input flooding is that when a target feature, "is very frequent in the input is likely to be noticed" (p.402). Through input flooding, teachers can put the target words and structures in the learners' center of attention to increase the absorption of the target structure.

In the present study, we were specifically interested in investigating which one of the techniques; that is, input enhancement that constitutes an explicit way of teaching or input flooding which is considered as an implicit teaching technique (Reinders \& Ellis, 2009) could be more effective in teaching the English passive voice to 
Iranian EFL learners. The incentive for comparing them was twofold. First, the techniques represented the distinction between explicit/implicit ways of teaching language forms to learners. Moreover, review of the literature shows conflicting results regarding the impact of input enhancement and input flooding. For example, Ellis (1999) reviewed eight studies and concluded that EFL learners could benefit from both textual enhancement and input flooding. Second, teaching the English passive voice is a challenging task mainly because of the lack conformity in the use of voice in Persian and English (Vahedi-Langrudi, 1996). For example, Guilani and Tan (2016) have pointed to some of the differences between passive voice in English and Persian. One difference, as they argued, is that the passive voice in English is mainly constructed by the various forms of the verb be and the past participial of the main verb while in Persian is not only structured by the verb Shodan but also various morphological alterations. Additionally, the verb Shodan bears meanings similar to possibility and going (Guilani \&Tan, 2016). Another argument is that passive structure does not exist in Persian (Moyne, 1974) which makes teaching it to Iranian EFL learners difficult. Therefore, investigating different techniques that can facilitate teaching the passive voice could be illuminating for Iranian EFL teachers. Moreover, EFL/ESL teachers can employ the techniques for teaching other grammatical structures that they find problematic. As Hinkel (2002) put forward, teaching the concept, use, and function of grammatical elements such as passive voice is demanding, and even some native speakers may have difficulties in mastering the grammar of English. Wang (2010) defined passive voice as a verb structure that is considered as a derivative of active voice, emerging due to peoples' different meaning expressions. As a marked form of voice, it involves the description of the whole process of a specific event from the patient's perspective. The structure frequently appears in academic texts and compositions, and university students need to learn it.

\subsection{Review of the Related Literature}

The acquisition of second language grammar has been a controversial and challenging issue due to many intricacies of SLA (Mystkowska-Wiertelak, 2012). According to the noticing hypothesis (Schmidt, 1990, 2001), input can become intake when learners pay attention to the language structure of the target language. In other words, some conscious attention is required when adults intend to learn the grammar of a language because they do not have access to the language learning ability they had as a child (Schmidt, 1983). Focus on Form instruction intends to raise learners' consciousness toward the target structure they are exposed to while learning a language (Sharwood Smith, 1981, 1991). Input flood and input enhancement are two of the activities that can raise learners' consciousness and facilitate learning grammar.

Many studies have so far been conducted to explore the differential impacts of input flooding and input enhancement on various language skills and components. In fact, most of the studies on input enhancement have addressed the acquisition of grammar. However, some studies have signified the efficacy of the technique (e.g., Jourdenais, Ota, Stauffer, Boyson, \&Daughty, 1995; Lee, 2007; White, 1998) while others did not find it to have any significant impact on the learning of the grammatical structures (e.g., Izumi, 2002; Leow, 2001; Leow, Egi, Nuevo, \& Tsai, 2003; Williams \& Evans, 1998). In a meta-analysis, Lee and Huang (2008) found that second language readers exposed to texts that contained enhanced items hardly did better than those who were exposed to texts in which the same target forms were flooded. Rikhtegar and Gholami (2015) reported the significant effect of pre-versus post-presentation input flooding via reading on the learning of the simple past tense. Afraz and Ebrahimi (2014) found that input enhancement and input flooding were both useful in learning the causative structure of English. Asadi Amirabadi, Biria, and Sedaghat (2014) concluded that the combination of input flood and input enhancement were more effective than the techniques separately in long-term retention of conditional structures by Iranian EFL learners. Likewise, Szudarski and Carter (2014) reported that input flood and input enhancement together were effective in the acquisition of collocations at the level of form recall and form recognition by Polish EFL learners. Hamed Mahvelati and Mukundan (2012) investigated the relative effectiveness of explicit (consciousness-raising approach) versus implicit (input flood) collocation instruction with regard to learners' knowledge of both lexical and grammatical collocations. The findings demonstrated that although both methods of teaching collocations were effective, the explicit method of consciousness-raising approach was significantly superior to the implicit method of input flood treatment. Alanen (1995) explored the impacts of textual enhancement and explicit rule presentation on adult learners of Finnish locative suffixes. Based on the findings of production task, it was revealed that both the explicit rule instruction group and textual enhancement plus explicit rule instruction group outperformed the control group, but they were not meaningfully different from each other.

The goal of the present study was to compare the effect of input enhancement and input flooding on learning English grammar passive voice by Iranian EFL learners. Thus, we formulated the following research question: 
RQ: Do input flooding and input enhancement techniques similarly affect Iranian EFL learners' knowledge of English grammar passive voice?

\section{Method}

\subsection{Participants}

Initially, 75 low-intermediate learners in six intact classes took Preliminary English Test (PET), and those whose scores fell within the range of \pm 1 standard deviation were selected. Thus, we discarded 15 participants whose scores lay beyond one standard deviation above and below the mean leading to the selection of 60 female learners with the age range of 19 to 23 who remained in their intact classes. These classes were then randomly assigned to receive two different techniques for learning the English passive voice. Thus, in each experimental group, there were three classes. The three classes in the experimental group one (Input Enhancement Group) were exposed to passive structures through input enhancement guidelines, and the three classes in the experimental group two (Input Flooding Group) received the same materials drawing on the guidelines in line with input flooding procedures. The reason for selecting six classes was the limited number of students in each class. However, the classes were taught by the same teacher to control teacher variable. It should be noted that the 15 discarded participants took part in the study, but their scores were not considered in the data analysis.

\subsection{Instrumentation}

We used PET to test the homogeneity of the participants. The test has reading and writing, listening, and speaking sections. The learners took the reading and writing sections in 90 minutes. The reading section has five parts with a total number of 35 questions to examine whether the test taker can read and understand the most important points from signs, newspapers, and magazines, and can use vocabulary and structure correctly. The writing section has seven questions. Five of the questions are filling in the blank type with five points, and there are two writing tasks one with 5 points and the other 15 points. Therefore, the total score for the reading and writing sections is 85 . The section on speaking allocates 15points to itself. Thus, the overall score for PET is 100. First, we piloted the test with 30 learners who were similar to the target population. Then we computed the reliability of the test through Cronbach's alpha. The test, according to Brown (2007), appeared to enjoy an acceptable reliability index ( $\mathrm{r}=0.76)$.

Another instrument was a 40-item teacher-made achievement test used as both the pretest and the posttest (Appendix A). It focused on the English passive structure in English. To check the content validity, we prepared a table of specifications and asked two English teachers who had been teaching English grammar for more than 10 years to review it (Brown, 2007). Then we piloted the test and estimated its agreement by the threshold loss agreement through the Subkoviak approach, which is used to compute the agreement (reliability) of criterionreferenced tests (Brown, 2007). The test was shown to have a satisfactory level of agreement ( $r=0.73)$.

\subsection{Materials}

We downloaded ten passages from the internet and modified them in line with Norris and Ortega (2000) and Nemati and Motallebzadeh (2013) for input enhancement and input flooding, respectively (Appendix B). The texts had topics such as a memorable party, an outing in Ramsar (a city in the north of Iran), the shard, a robbery report, Jack the ripper each containing around 150 words. In the input enhanced group, the passive structures in the passages were visually enhanced through boldfacing, italicizing, highlighting, and capitalizing. For the input flooding, the frequency of the passive structures in the text was raised. In other words, passive structures were used several times in the texts. All participants studied Top Notch 2 (Saslow \& Ascher, 2006) as their textbook.

\subsection{Procedure}

\subsubsection{Pretest}

Before the treatment, the participants sat for PET and grammar test to ensure that they were homogeneous, and there was no statistically significant difference between them regarding knowledge about the English passive voice.

\subsubsection{Treatment}

The classes met twice a week, each week two sessions. The duration of each session was one hour and a half. The study took 13 sessions. Three sessions were allotted to administering the tests, and the treatment was given in 10 sessions. We should mention that only about 45 minutes was allocated to reading the passages and practicing the passive voice. There were other activities related to routines of the classes.

\subsubsection{Input Enhancement Groups}

In the input enhancement groups, the passive structures used in the passages were enhanced drawing on Norris and Ortega's (2000) guidelines for input enhancement. The techniques used included boldfacing, italicizing, 
highlighting, and capitalizing. It is worth mentioning that at the end of the passages, some reading comprehension questions were also provided. More specifically in this group, we pursued the following steps:

- First, the teacher asked some warm-up questions related to the topic before giving the passages to the students.

- Then the students were put into pairs to discuss the warm-up questions.

- Following that, the participants started reading the passages silently.

- The teacher drew their attention toward the enhanced content of the passages and asked them to pay attention to the structures that were written in a different mode.

- As the next step, the learners answered the comprehension questions at the end of the passage.

- Then, the teacher explained the passive structure related to the passage (meta-linguistic awareness).

- In the end, the teacher asked the students to write down as many passive structures as they could remember from the classroom activities on paper strips and hand them over.

\subsubsection{Input Flooding Groups}

In input flooding groups, the participants were flooded with the passive structures used in the passages in line with Nemati and Motallebzadeh (2013) in which "increasing the frequency of appearance of a given feature in the input, makes such feature more prominent in EFL input series, and this is known to be input flooding" (p. 409). In a similar vein, the learners were exposed to the passive structures used several times in the passages. More specifically in these groups, we followed these steps:

- First, the teacher asked some warm-up questions related to the topic before giving the passage to the students.

- Second, the students were put into pairs to discuss the warm-up questions.

- Third, the teacher gave the passages to the learners and asked the students to read the passages silently.

- As the next step, the participants read aloud the passages.

- Then the class answered the teacher's questions regarding the content of the passages. She tried to pose questions in the passive voice and elicit the students' answers in the passive voice as much as possible.

- The teacher answered the students' questions (if there were any).

- Similar to the Input Enhancement group, the teacher asked the students to write down as many passive structures as they could remember from the classroom activities on paper strips and hand them over.

As it is clear, the treatment in both groups was in line with the explicit/implicit dichotomy.

\subsubsection{Posttest}

After the treatment, the researcher gave the participants in both groups the same teacher-made grammar test to measure their gain of the passive structures after the treatment.

\section{Results}

\subsection{Language Proficiency}

Table 1 shows the descriptive statistics of the initial 75 low-intermediate language learners regarding PET scores.

Table 1. Descriptive statistics of 75 language learners on PET

\begin{tabular}{llllll}
\hline & $\mathrm{N}$ & Minimum & Maximum & Mean & Std. Deviation \\
\hline PET & 75 & 35.00 & 50.00 & 42.4933 & 3.57685 \\
Valid N (listwise) & 75 & & & & \\
\hline
\end{tabular}

Table 2 shows the descriptive statistics of the 60 language learners whose scores fell within the range of \pm 1 standard deviation. As seen in Table 2, the number of students has reduced to $60(\mathrm{M}=42.41, \mathrm{SD}=2.43)$. When compared to the mean score of initial 75 language learners, the mean score of 60 students has not changed much which is an indication of the fact that mean score has been a good indicator of the central point of scores' distribution. On the other hand, SD has reduced from 3.57 to 2.43 , which means that the dispersion of scores has been half reduced and scores enjoy more homogeneity. As mentioned above, 60 language learners stayed in their intact classes during the course of the study. The six classes were then randomly assigned to Input Enhancement groups and Input Flooding groups. 
Table 2. Descriptive statistics of 50 language learners on PET

\begin{tabular}{llllll}
\hline & $\mathrm{N}$ & Minimum & Maximum & Mean & Std. Deviation \\
\hline PET homogenized & 60 & 38.00 & 47.00 & 42.4167 & 2.43764 \\
Valid N (listwise) & 60 & & & & \\
\hline
\end{tabular}

\subsection{Parametric Test Assumptions}

Another consideration before running the main statistical analysis was the choice between parametric and nonparametric statistics. In other words, it was necessary to examine whether the distribution of the scores on PET was normal. Table 3 shows the results of Kolmogorov-Smirnov (K-S) test. As shown in the table, there are four sets of data including the grammar pretest and posttest data obtained from each group. Moreover, as Table 3 shows, significant levels related to Kolmogorov-Smirnov test of normality for pretest are greater than 0.05 level of significance indicating the normality of the pretest scores. However, the significant levels related to KolmogorovSmirnov test for the posttest are smaller than 0.05 level of significance showing that the distribution of the scores was not normal.

Table 3. Results of the normality on four sets of data

\begin{tabular}{lllll}
\hline & & \multicolumn{2}{l}{ Kolmogorov-Smirnov (K-S) } \\
\cline { 3 - 5 } & Groups & Statistic & $\mathrm{df}$ & Sig. \\
\hline Pretest & Input Flooding & .113 & 30 & $.200^{*}$ \\
& Input Enhancement & .107 & 30 & $.200^{*}$ \\
Posttest & Input Flooding & .229 & 30 & .000 \\
& Input Enhancement & .209 & 30 & .002 \\
\hline
\end{tabular}

\subsection{Homogeneity of Participants in Terms of Knowledge of Passive Structure}

Before the experimentation, it was also needed to examine the homogeneity of the two groups regarding knowledge of the passive voice. Accordingly, the grammar test was administered and the obtained scores were analyzed using independent samples t-test. Table 4 shows the descriptive statistics.

Table 4. Descriptive statistics of the two groups of the study on grammar pretest

\begin{tabular}{llcccc}
\hline & Groups & $\mathrm{N}$ & $\mathrm{Mean}$ & Std. Deviation & Std. Error Mean \\
\hline \multirow{2}{*}{ Pretest } & Input Flooding & 30 & 17.8000 & 4.01205 & .73250 \\
& Input Enhancement & 30 & 18.1333 & 4.16664 & .76072 \\
\hline
\end{tabular}

In order to make sure that the mean scores of the two groups were not significantly different, independent samples t-test was run on the pretest scores. Table 5 shows the results. The Levene's test showed that the variances were homogeneous $(\mathrm{F}=0.22, p>0.05)$, and accordingly, the $\mathrm{t}$-test indicated no significant difference between the means of the groups $\mathrm{t}(58)=0.31, p>0.05)$.

Table 5.The results of independent samples t-test on pretest scores

\begin{tabular}{|c|c|c|c|c|c|}
\hline & & Levene's Test for Equality of Variances & t-test for Equality & f Means & \\
\hline Pretest & $\begin{array}{l}\text { Equal variances } \\
\text { assumed }\end{array}$ & .220 & -.316 & -.33333 & 1.05605 \\
\hline
\end{tabular}




\subsection{Answering the Research Question}

To answer the research question, the groups' scores on the grammar posttest were compared. Table 6 shows the results.

Table 6. Descriptive statistics of the groups

\begin{tabular}{llccll}
\hline \multirow{4}{*}{ Posttest } & Groups & $\mathrm{N}$ & Mean & Std. Deviation & Std. Error Mean \\
& Input Flooding & 30 & 24.7667 & 3.99727 & .72980 \\
& Input Enhancement & 30 & 25.0000 & 3.15135 & .57536 \\
\hline
\end{tabular}

Mann-Whitney U test was run between the posttest means of the Input Flooding and Input Enhancement groups to examine whether there was any significant difference between the groups in terms of knowledge of the passive voice.

Table 7. Results of Mann-Whitney U test

\begin{tabular}{ll}
\cline { 2 - 2 } & \multicolumn{1}{c}{ Posttest } \\
\cline { 2 - 3 } Mann-Whitney U & 449.000 \\
Wilcoxon W & 914.000 \\
Z & -.015 \\
Asymp. Sig. (2-tailed) & .988 \\
\hline
\end{tabular}

a. Grouping Variable: Groups

As Table 7 shows, $\mathrm{U}$ value was found 0.449 .00 ( $p>0.05$ ), which indicated no significant difference between the groups. It was concluded that input flooding and input enhancement have the same effect on the students' knowledge of the passive voice. Based on the obtained results the researchers failed to reject the null hypothesis.

\section{Discussion}

The current study focused on teaching the passive voice though input enhancement and input flooding. The results showed that although both techniques were useful in learning the passive voice, no significant differences were found to demonstrate the superiority of one of the techniques to the other. It seems that input enhancement and input flooding can provide the input learners need for developing grammar knowledge. In other words, the type of input provided by the two techniques is sufficient for learning the target form (passive voice). Moreover, the results of this study find support from the literature on FonF (e.g., Doughty \& Williams, 1998; Robinson, 2001; Skehan, 2003; Spada, 1997; Swain, 1985) since both techniques are associated with FonF activities (Doughty and Williams, 1988). Therefore, we can claim that enhanced input and flooded input are both successful in drawing learners' attention to the rules of the language. The manipulation of either of the techniques, as the result of the study shows, can enhance learning grammar. However, as mentioned in the introduction section, each of the activities is related to the explicit and implicit ways of teaching grammar. The findings of the present study may suggest EFL teachers use a combination of both techniques and benefit from both implicit and explicit teaching. Furthermore, based on the findings, we can recommend EFL teachers to use both techniques in their classes because each of them as the samples of explicit and implicit teaching may have their merits and demerits.

An additional point to mention is related to the passive structure in Persian. As explained above, passive voice is a complex grammatical structure for Iranian EFL learners because as some researchers argued, it does not exist in Persian or its structure is different from English (Moyne, 74; Vahedi-Langrudi, 96). The fact that explicit and implicit FonF instructions are useful in teaching the passive voice contradicts Andrews (2007) who found that for teaching complex rules, explicit grammar teaching is more appropriate. Also, the result of this study is inconsistent with Tode (2007) and Radwan (2005) who found that explicit teaching of grammar enhances the learning of grammatical rules.

\section{Conclusions}

The present study can be placed in the domain of FonF studies. However, its results show that the explicit/implicit dichotomy is still a controversial issue. The findings highlight the role of exposure to linguistic input while the learners' attention is focused on the form they are being taught. The fact that input flooding and input enhancement both could enhance the participants' learning of the passive structure reveals that teachers should manipulate 
different techniques and strategies to solve learners' learning problems. Also, the study contributes to the theory of noticing hypothesis (Schmidt, 1990). We suggest researchers compare input enhancement and input flooding techniques with a control group that does not receive consciousness-raising activities. Additionally, it would be a good idea to examine the outcomes of manipulating both techniques concurrently with regard to simple and complex grammatical features of English.

\section{References}

Afraz, S., \& Ebrahimi, S. (2014).The comparative effect of input flooding vs. visual input enhancement on learning causative structures. International Journal of Educational Investigations, 13(4), 21-35.

Alanen, R. (1995). Input enhancement and rule presentation in second language acquisition. In R. Schmidt (Ed.), Attention and awareness in foreign language learning. Honolulu, University of Hawai'i Press Second Language Teaching \& Curriculum Center.

Andrews, K. L. Z. (2007). The effects of implicit and explicit instruction on simple and complex grammatical structures for adult English language learners. TESL-EJ, 11(2). Retrieved from http://tesl-ej.org/ej42/a5.html

Asadi Amirabadi, Y., Biria, R., \& Sedaghat, A. (2014). Efficacy of input flood vs. input enhancement in the learning and long-term retention of conditionals by intermediate Iranian EFL students. International Journal of Language Learning and Applied Linguistics World, 7(3), 562-575.

Brown, J. D. (2007). Testing in language programs. New York, NY: Mc GrawHill.https://doi.org/10.1177/0265532207072561

Doughty, C., \& Williams, J. (1998). Pedagogical choices in focus on form. In C. Doughty \& J. Williams (Eds.), Focus on form in classroom second language acquisition (pp. 197-261). Cambridge: Cambridge University Press.

Ellis, R. (1999). Input-based approaches to teaching grammar: A review of classroom-oriented research. Annual Review of Applied Linguistics, 19(1), 64-80. https://doi.org/10.1017/S0267190599190044

Gass, S. M., \& Selinker, L. (2001). Second language acquisition: An introductory course. London: Routledge.

Guilani, M. A., \& Tan, K. H. (2016). English passive and the function of shodan in Persian.Asian Social Science, 12(9), 162-175. http://dx.doi.org/10.5539/ass.v12n9p162

Hamed, M. E. (2012). The effects of input flood and consciousness-raising approachon collocation knowledge development of language learners. International Journal of Applied Linguistics \& English Literature, 12(1), 182-194. http://dx.doi.org/10.7575/ijalel.v.1n.6p.182

Hinkel, E. (2002). Why English passive is difficult to teach (and learn). In E. Hinkel \& S. Fotos (Eds.). New perspectives on grammar teaching in second language classrooms (pp. 233-259). New York, NY; Lawrence Erlbaum.

Izumi, S. (2002). Output, and input enhancement, and the noticing hypothesis: An experimental study of ESL, relativization. Studies in Second Language Acquisition, 24(4), 541-577. https://doi.org/10.1017/S0272263102004023

Jourdenais, R., Ota, M., Stauffer, S., Boyson, B., \& Doughty, C. (1995). Does textual enhancement promote noticing? A think-aloud protocol analysis. In R. Schmidt (Ed.).Attention and Awareness in Foreign Language Learning (pp. 183-216). Honolulu: Second Language Teaching and Curriculum Center, the University of Hawaii at Manoa.

Lee, S. K. (2007). Effects of textual enhancement and topic formality on Korean EFL students' reading comprehension and learning of passive form. Language Learning, 57, 87-118. http://doi.org/10.1111/j.14679922.2007.00400.x

Lee, S. K., \& Huang, H. T. (2008). Visual input enhancement and grammar learning: A meta-analytic review. Studies in Second Language Acquisition, 30(3), 307-331. https://doi.org/10.1017/S0272263108080479

Leow, R. P. (2001). Attention, awareness, and focus on form research: A critical overview. In J. Lee \& A. Valdman (Eds.), Form and meaning: Multiple perspectives. Boston, Mass: Heinle \& Heinle.

Leow, R. P., Egi, T., Nuevo, A. M., \& Tsai, Y. C. (2003).The roles of textual enhancement and type of linguistic item in adult L2 learners' comprehension and intake. Applied Language Learning, 13, 1-16.

Moyne, J. A. (1974). The so-called passive in Persian. Foundations of Language, 12(2), 249-267.

Mystkowska-Wiertelak, A. (2012). Theoretical perspectives on grammar learning and teaching. In A. Mystkowska- 
Wiertelak \& M. Pawlak (Eds.). Production-oriented and comprehension-based grammar teaching in the foreign language classroom (pp. 29-59). Berlin: Springer. https://doi.org/10.1007/978-3-642-20856-0

Nemati, F., \& Motallebzadeh, K. (2013). Input flooding: A factor to improve Iranian pre-intermediate EFL learners' structural accuracy. British Journal of Education, Society \& Behavioral Science, 3(4), 407-418. https://doi.org/10.9734/BJESBS/2013/4452

Norris, J., \& Ortega, L. (2000). Effectiveness of EFL instruction: A research synthesis and quantitative metaanalysis. Language Learning, 50(5), 417-528. https://doi.org/10.1111/0023-8333.00136

Radwan, A. (2005). The effectiveness of explicit attention to form in language learning. System, 33, 69-87. http://dx.doi.org/10.1016/j.system.2004.06.007

Reinders, H., \& Ellis, R. (2009). The effects of two types of input to intake and the acquisition of implicit and explicit knowledge. In R. Ellis, S. Loewen, C. Elder, R. Erlam, J. Philp, \& H. Reinders (Eds.), Implicit and explicit knowledge in second language learning, testing, and teaching (pp.281-302). Bristol: Multilingual Matters. https://doi.org/10.21832/9781847691767

Rikhtegar, O., \& Gholami, J. (2015). The effects of pre- versus post-presentation input flooding via reading on the young Iranian EFL learners' acquisition of simple past tense. English Language Teaching, 7(8), 80-88. http://doi:10.5539/elt.v8n3p80

Robinson, P. (2001). Task complexity, cognitive load, and syllabus design. In P. Robinson (Ed.), Cognition and secondlanguage instruction, Cambridge: Cambridge University Press. https://doi.org/10.1017/CBO9781139524780

Saslow, J., \& Ascher, A. ( 2006). Top notch 2. London: Pearson Longman.

Schmidt, R. (1983). Interaction, acculturation and the acquisition of communicative competence. In N. Wolfson \& E. Judd, (Eds.), Sociolinguistics and language acquisition (pp. 137-174). Rowley, MA: Newbury House.

Schmidt, R. (1990). The role of consciousness in second language learning. Applied Linguistics, 11(2), 129-158. https://doi.org/10.1093/applin/11.2.129

Schmidt, R. (2001). Attention. In P. Robinson (Ed.), Cognition and second language instruction (pp.3-32). Cambridge: Cambridge University Press. https://doi.org/10.1017/CBO9781139524780.003

Sharwood, S. M. (1981). Consciousness-raising and the second language learner. Appliedc Linguistics, 2, 159-168. https://doi.org/10.1093/applin/2.2.159

Sharwood, S. M. (1993). Input enhancement in instructed SLA: Theoretical bases. Studies in Second Language Acquisition, 15(1), 165-179. http://dx.doi.org/10.1017/S0272263100011943

Sharwood, S. M. (1991). Speaking to many minds: On the relevance of different types of language information for the L2 learner. Second Language Research, 7(2), 118-132. https://doi.org/10.1177/026765839100700204

Skehan, P. (2003). Task-based instruction. Language Teaching, 36(1), 1-14. https://doi.org/10.1017/S026144480200188X

Spada, N. (1997). Form-focused instruction and second language acquisition: Review of classroom and laboratory research. Language Teaching, 30, 73-87. https://doi.org/10.1017/S0261444800012799

Swain, M. (1985). Communicative competence: Some roles of comprehensible input and comprehensible output in its development. In S. Gass \& C. Madden (Eds.), Input in second language acquisition, (pp. 235-256). New York, NY: Newbury House.

Szudarski, P., \& Carter, R. (2014). The role of input flood and input enhancement in EFL learners' acquisition of collocations. International Journal of Applied Linguistics, 26(2), 245-265. https://doi.org/10.1111/ijal.12092

Tode, T. (2007). Durability problems with explicit instruction in an EFL context: The learning of the English copula be before and after the instruction of the auxiliary be. Language Teaching Research, 11(1), 11-30. Retrieved from Academic Search Complete database. https://doi.org/10.1177/1362168806072398

Vahedi-Langroodi, M. M. (1996). The syntax, semantics and argument structure of complex predicates in modern Farsi. (unpublished doctoral dissertation). University of Ottawa, Canada. http://dx.doi.org/10.20381/ruor7974

Wagner-Gough, J., \& Hatch, E. (1975). The importance of input data in second language acquisition studies. Language Learning, 25(2), 297-308. https://doi.org/10.1111/j.1467-1770.1975.tb00248.x 
Wang, Y. (2010). Classification and SLA studies of passive voice. Journal of Language Teaching and Research, 1(6), 945-949. https://doi.org 10.4304/jltr.1.6.945-949

White, J. (1998). Getting the learner's attention. A typographical input enhancement study. In C. Doughty \& J. Williams (Eds.), Focus on form in classroom second language acquisition (pp. 85-114). Cambridge: Cambridge University Press.

Williams, J., \& Evans, J. (1998). What kind of focus and on which forms? In C. Doughty \& J. Williams (Eds.), Focus on form in classroom L2 acquisition (pp. 139-155). New York, NY: Cambridge University Press.

\section{Appendix A}

\section{Test of Passive Structures}

Name:

\section{Section (A): Choose the correct option.}

1. They were interviewing her for the job.

She for the job.
a) was being interviewed
b) was interviewed
c) will be interviewed
c) has been interviewed
2. Tom is writing the letter.

The letter by Tom.
a) was written
b) had written
c) is being written
d) has been written
3. Everyone understands English.

English by everyone.

a) is understood

b) has been understood

c) was understood

d) was being understood

4. The employees brought up this issue during the meeting.

This issue by the employees during the meeting.
a) has been brought up
b) is brought up
c) was brought up
d) was bringing up

5. The professor told him not to talk in class.

$\mathrm{He}$ by the professor not to talk in class.
a) will be told
b) has been told
c) was told
d) was being told
6. They say that women are smarter than men.

Women to be smarter than men.

a) were being said 

b) was being said
c) were said
d) are said

7. The fire has destroyed the house.

The house by the fire.
a) has been destroyed
b) was being destroyed
c) is destroyed
d) was destroyed

8. She asked you to help her.

You by her.
a) were helped
b) were asked
c) asked
d) was being helped
9. She would reject the offer. The offer
a) will have been rejected
b) would be rejected
c) was being rejected
d) will be rejected by her.

10. This surprises me.

I__ by this.

a) would have been surprised

b) will be surprised

c) am surprised

d) will surprise

11. They passed me up for that position.

I for that position.
a) was passed up
b) was being passed up
c) will be passed up
d) am passed up

12. Tomorrow, I will buy the car.

Tomorrow, the car by me.
a) will being bought
b) will have been bought
c) was bought
d) will be bought

13. John bought the Picasso painting. The Picasso painting by John.
a) was bought
b) will have been bought
c) is bought 
d) will be bought

14. Most students misunderstand this story.

This story by most students.

a) was misunderstood

b) will be misunderstood

c) has been misunderstood

d) is misunderstood

15. My brother carried the groceries into the room.

The groceries by my brother into the room.
a) were being carried
b) have been carried
c) were carried
d) was being carried

16. Juan is preparing the dinner. The dinner by Juan.
a) are being prepared
b) were being prepared
c) is prepared
d) are prepared

17. His brother was telling him to calm down.

$\mathrm{He}$ to calm down by his brother.
a) is being told
b) was being told
c) was told
d) is told

18. A dog bit me.

I by a dog.
a) was being bitten
b) was bitten
c) have been bitten
d) are written

19. The movers have delivered the furniture.

The furniture by the movers.
a) will have been delivered
b) would be delivered
c) has been delivered
d) are delivered

20. This city will surprise you. You by this city.
a) are surprised
b) will be surprised
c) will have been surprised
d) will surprise

\section{Section (B)}

Everyone in the house has a task that he or she normally does. Describe what everyone does, changing each active voice sentence into a passive voice sentence: 
EX: John buys the food. --> The food is bought by John.

21. Thomas washes the dishes. --> The dishes .... by Thomas.

22. Frank feeds the dogs. --> ................... The dogs by Frank.

23. Maria prepares the food. --> The food by Maria.

24. David cleans the kitchen. --> The kitchen by David.

25. My father pays the bills. --> The bills by my father.

26. The gardener trims the bushes. --> The bushes by the gardener.

27. Helen sets the table. --> The table by Helen.

28. My mother waters the plants. --> The plants by my mother.

29. Arthur does the laundry. --> The laundry by Arthur.

30. My uncle drives us to school. --> We to school by my uncle.

\section{Section (C)}

Fill in the blanks to change each active voice sentence into a passive voice sentence: Ex: Henry Miller wrote that book. --> That book was written by Henry Miller.

31. The cook prepared the dinner. --> The dinner by the cook.

32. My brother repaired the roof. --> The roof by my brother.

33. A friend of ours showed him around town. --> He around town by a friend of ours.

34. The dog ate the cookies. --> The cookies by the dog.

35. My neighbor bought the flowers. --> The flowers by my neighbor.

36. Henry's dad adopted that puppy. --> That puppy by Henry's dad.

37. Rita's boss gave her a raise. --> Rita a raise by her boss.

38. Robert ironed the clothes. --> The clothes by Robert.

39. The teacher questioned him about the essay. --> He by his teacher about the essay.

40. The committee awarded them the first prize. --> They the first prize by the committee.

Total Score......./40

\section{Appendix B}

\section{Sample Input Enhancement Materials}

\section{A Memorable Party}

I am now lying in my bed.I want to tell you about a great yesterday. Yesterday, I was invited to a birthday party. It was very enjoyable. A birthday party is held for marking the memory of someone's birthday. The friends and the relatives are usually invited to the party.

Yesterday when I arrived, the foods were being served and the music was being played. I saw many gentlemen sitting around the tables. I was requested by Bill, the party host and my friend, to sit beside him. To my surprise, I was introduced to some of my old friends who I had not seen for a long time. I became very happy to see them.

We talked for many hours and briefed each other on what had happened in the previous years. As we were talking, some call numbers and photos were being exchanged between us. That night was a memorable night for me and my friends.

Now as the memories from yesterday ARE BEING REVIEWED, I wish I could attend a similar party again.I also hope I will keep contact with my newly found friends forever.

The door IS BEING KNOCKED on. I have to go .bye for now.

\section{Reading Comprehension Questions}

1-What was going on in the party when I arrived?

2-Why is birthday party held? 
3-Where did Bill request me to sit?

4-At the end of the narration, why should I go?

\section{Sample Input Flooding Materials}

\section{A Memorable Party}

Read the following text and answer the questions that follow.

I am now lying in my bed. I want to tell you about a great yesterday. Yesterday, I was invited to a birthday party. It was very enjoyable. A birthday party is held for marking the memory of someone's birthday. The friends and the relatives are usually invited to the party. Yesterday when I arrived, the foods were being served and the music was being played. I saw many gentlemen sitting around the tables. I was requested by Bill, the party host and my friend, to sit beside him. To my surprise, I was introduced to some of my old friends who I had not seen for a long time. I became very happy to see them. We talked for many hours and briefed each other on what had happened in the previous years. As we were talking, some call numbers and photos were being exchanged between us. That night was a memorable night for me and my friends.

Now as the memories from yesterday are being reviewed, I wish I could attend a similar party again. I also hope I will keep contact with my newly found friends forever. The door is being knocked on. I have to go bye for now.

Reading Comprehension Questions

1-What was going on in the party when I arrived?

2-Why is birthday party held?

3-Where did Bill request me to sit?

4-At the end of the narration, why should I go?

\section{Copyrights}

Copyright for this article is retained by the author(s), with first publication rights granted to the journal.

This is an open-access article distributed under the terms and conditions of the Creative Commons Attribution license (http://creativecommons.org/licenses/by/4.0/). 